\title{
Wild boar (Sus scrofa scrofa) hunting and exploitation strategies during the Mesolithic at Les Cabônes (Ranchot Jura, France), layer 3
}

\author{
Charlotte Leduc ${ }^{\mathrm{a}, *}$, Anne Bridault ${ }^{\mathrm{b}}$, Christophe Cupillard ${ }^{\mathrm{c}, \mathrm{d}}$ \\ a UMR 8215, Trajectoires, De la sédentarisation à l'État, Maison de l'Archéologie et de l'Ethnologie, 21 allée de l'Université, 92000 Nanterre, France \\ b CNRS, UMR 7041, ArScAn, Equipe Archéologies environnementales, Maison de l'Archéologie et de l'Ethnologie, 21 allée de l'Université, 92000 Nanterre, France \\ ' Service Régional d'Archéologie de Franche-Comté, 7 rue Charles Nodier, 25043 Besançon cedex, France \\ d UMR 6249 du CNRS, Laboratoire de Chronoenvironnement, UFR des Sciences et des Techniques, 16, Route de Gray, 25030 Besançon cedex, France
}

\section{A R T I C L E I N F O}

\section{Article history:}

Received 19 February 2015

Received in revised form 8 May 2015

Accepted 9 May 2015

Available online $\mathrm{xxxx}$

Keywords:

Sus scrofa scrofa

Aging

Mortality profiles

Hunting strategies

Zooarchaeology

Mesolithic

\begin{abstract}
A B S T R A C T
Wild boar (Sus scrofa scrofa) is one of the key subsistence resources, together with red deer (Cervus elaphus) during the Mesolithic period in Western Europe. However, the hunting strategies and exploitation patterns involved are still only sparsely documented. The meticulous recovery techniques during excavation and the good preservation of the faunal material from Mesolithic layer 3 of "Les Cabônes" rockshelter (Ranchot, Jura), dated between 8200 and 7300 cal BC, offered the opportunity to analyze a large sample of wild boar remains, including a high proportion of teeth. The present paper focuses on the reconstruction of wild boar mortality profiles with a reappraisal of the aging methods based on tooth eruption and wear stages. The validity of available reference data sets and their application to archaeological samples is also discussed. The results show that Mesolithic hunters at "Les Cabônes" mostly targeted sounders, i.e. sows with their piglets, ensuring a steady food supply and occasionally solitary males that would certainly provide a greater amount of meat and grease per individual, as well as ivory from tusks. The carcasses of hunted animals were transported to the site either complete or semi-complete on a regular (multi-seasonal) basis, to be butchered and probably consumed onsite. Finally, comparisons with regional data are discussed in terms of patterns of site occupation.
\end{abstract}

\section{Introduction}

In recent decades, archaeofaunal studies have demonstrated the importance of wild boar (Sus scrofa scrofa) in the subsistence economy during most of the Mesolithic period in Northern and Eastern France and in western Switzerland.

In assemblages dated 9500-7000 cal BC in the Jura area, wild boar and red deer (Cervus elaphus) are almost always the two main hunted species, as exemplified at the following sites: Rochedane, layer A3 and Mannlefelsen I, layers Q-L (Bridault, 1990, 1993); Bavans layer 6 (Aimé, 1993); Choisey, level C2, and Ruffey-sur-Seille, levels R4, R3 and R2 (Séara et al., 2002); Dammartin-Marpain, locus 1 to 16 (Leduc in Séara and Roncin, 2010; Séara and Roncin, 2013); Mollendruz, layer 4d (Chaix in Pignat and Winiger, 1998); Ogens, layers C2 to C13-14 (Bridault and coll. P. Chiquet, 2000); Birsmatten, levels H5-H3 (Schmid, 1963) (Fig. 1).

At the present time, it is clear that in northern France, where numerous sites are located in the Seine and Somme valleys and its tributaries,

\footnotetext{
* Corresponding author.

E-mail addresses: charlotte.leduc@mae.u-paris10.fr (C. Leduc), anne.bridault@mae.u-paris10.fr (A. Bridault), christophe.cupillard@culture.gouv.fr (C. Cupillard)
}

wild boar became dominant in the assemblages dated between 8600 and 7800 cal BC (Marinval-Vigne et al., 1989; Bridault, 1997; Ducrocq et al., 2008, 2014; Coutard et al., 2010; Séara et al., 2010; Bignon-Lau et al., 2013; Leduc et al., 2013).

Despite the apparent importance of the wild boar in the subsistence economy of these Mesolithic groups, the hunting strategies and exploitation patterns involved are still only sparsely documented. One of the authors $(A B)$ has stressed that wild boar hunting at Rochedane was focused on the primary social group (Bridault, 1993: 486-490, 1994: 63), i.e., a few sows, their last litters and juvenile offspring of previous litters (Mauget, 1981). It was also suggested that hunters could thus take advantage of targeting several animals at once. Such groups are the most easily located, as their mobility is more circumscribed than solitary males, and encountered more frequently, as they often take the same routes when wandering (Mauget, 1981).

The abundant boar remains, including a high proportion of teeth, identified in the Mesolithic assemblage from layer 3 at Les Cabônes rockshelter (Ranchot, Jura) (Fig. 1), offered the opportunity to study the hunting strategies and carcass exploitation patterns at this site. The analysis was done as part of a Master's thesis (Leduc, 2005). The present paper addresses these issues, with an emphasis on the reconstruction of age-at-death distributions, i.e., mortality profiles. 


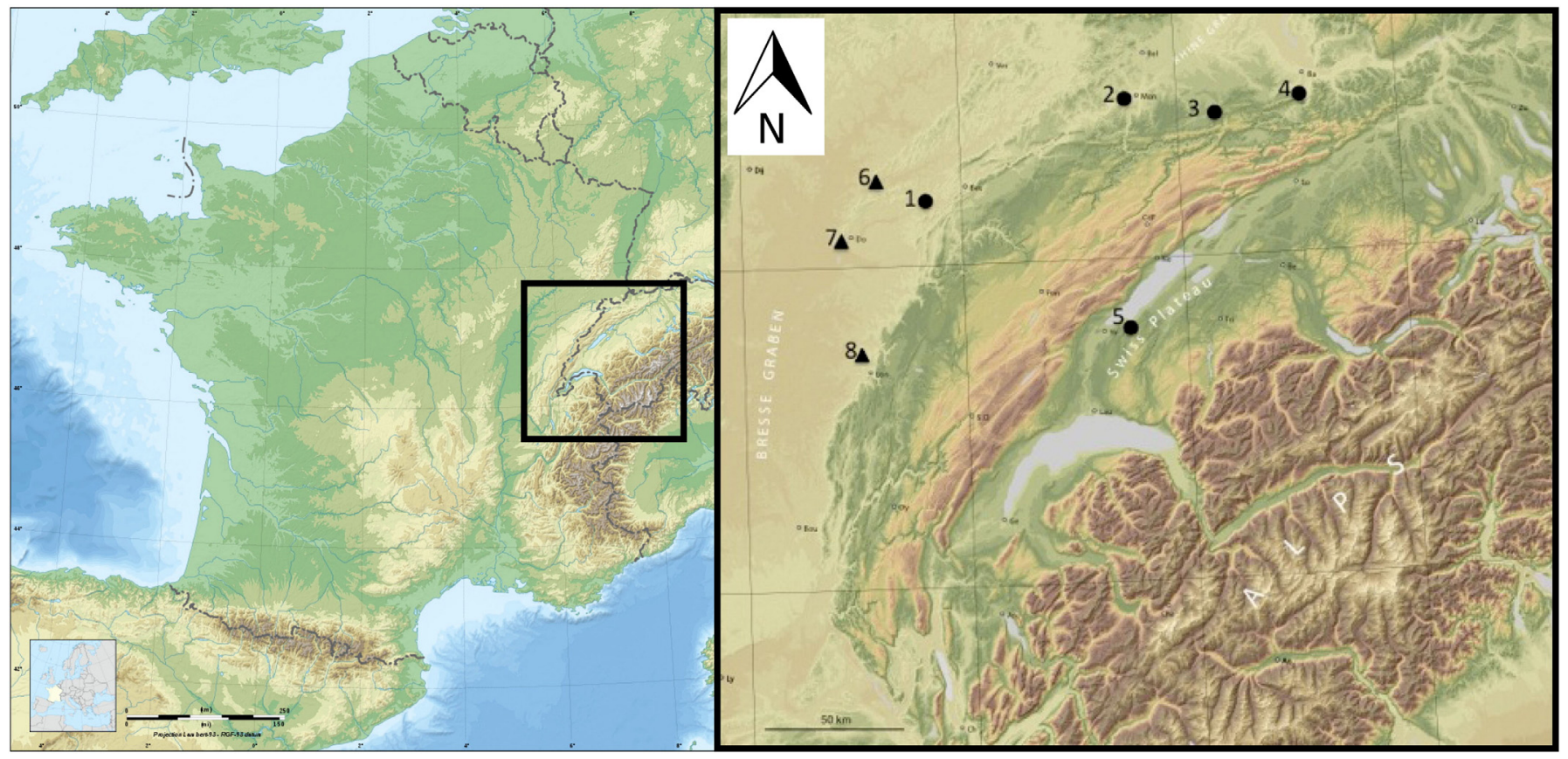

Fig. 1. Location of the Mesolithic sites of the Jura area cited in this paper: circle (map of France from Cartesfrance.fr) = cave or rockshelter; triangle = open air sites. 1 - "Les Cabônes", rockshelter, Ranchot, (Jura, France); 2 - "Bavans", rockshelters, Bavans (Doubs, France); 3 - "Mannlefelsen I", rockshelter, Oberlag (Haut-Rhin, France); 4 - "Birsmatten", cave, Nenzlingen (Bern canton, Switzerland); 5 - "La Baume d'Ogens", cave, Ogens (Vaud canton, Switzerland); 6 - "Prairie du Milieu" open air site, Dammartin-Marpain (Jura, France); 7 - "Aux Champins", open air site, Choisey (Jura, France); 8 - "A Daupharde", open air site, Ruffey-sur-Seille (Jura, France).

\section{The site}

Les Cabônes rockshelter, also called "Abri du Colonel Martin” is located near the town of Ranchot (Jura), midway between Besançon (Doubs) and Dole (Jura) (Fig. 1). It is situated on the right bank of the Doubs River, very close to the river, at an altitude of $216 \mathrm{~m}$. The cavity is quite small, $5 \mathrm{~m}$ deep, $4 \mathrm{~m}$ wide and $2.5 \mathrm{~m}$ high, oriented south-west and opening onto a wide rockshelter ca. $10 \mathrm{~m}$ long (Cupillard, 1998a, 2002, Fig. 2).

Following test excavations during the 1950s and 1960s, large-scale excavations were undertaken from 1978 to 1989, directed by A. Thévenin,
M. Campy, S. David and C. Cupillard (David, 1996; Cupillard, 1998a; Cupillard and David, 1991, 1995; Cupillard and Richard, 1999). The stratigraphy contains four main layers with an Upper Magdalenian occupation in layer 4 (David, 1996; D'Errico and David, 1993; Cupillard, 1998a) and several Mesolithic occupations in layer 3 and the lower part of layer 2 (Fig. 3).

Layer 3 is 60 to $70 \mathrm{~cm}$ thick and was excavated over a surface area of $50 \mathrm{~m}^{2}$ but probably covers $80 \mathrm{~m}^{2}$ into the rockshelter, as suggested from test excavations. Its preservation is irregular depending on topography and the sectors excavated. The layer is absent in the cave where it was destroyed by old excavations while it is well-preserved between the

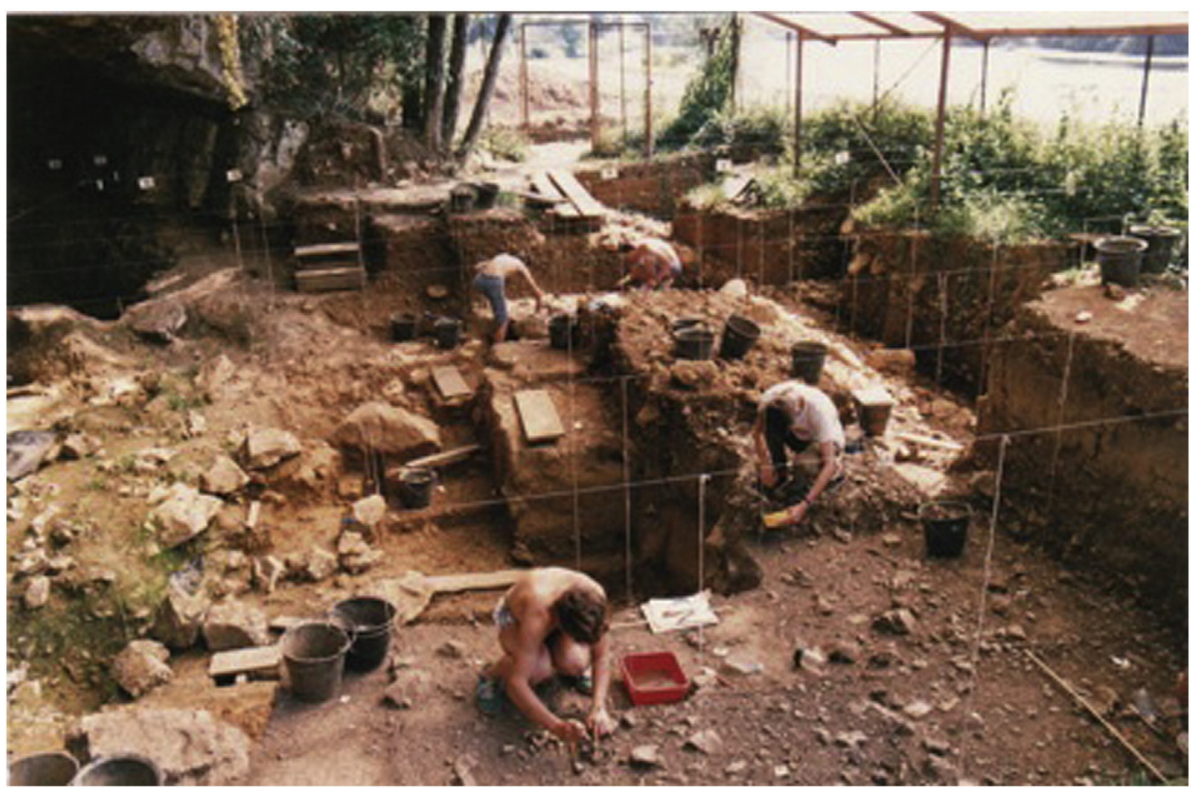

Fig. 2. Excavation of "Les Cabônes" rockshelter (1988). General view towards the east with black layer 3 in the foreground. (c) C. Cupillard. 
Limit between lines C\&D

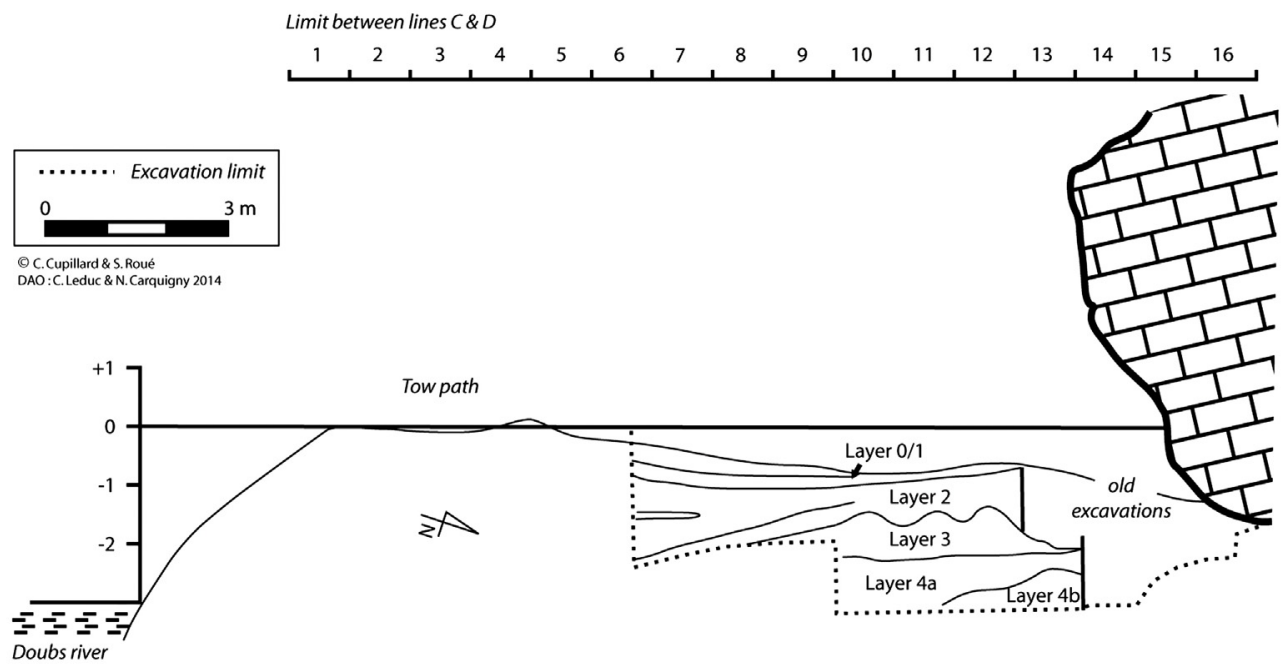

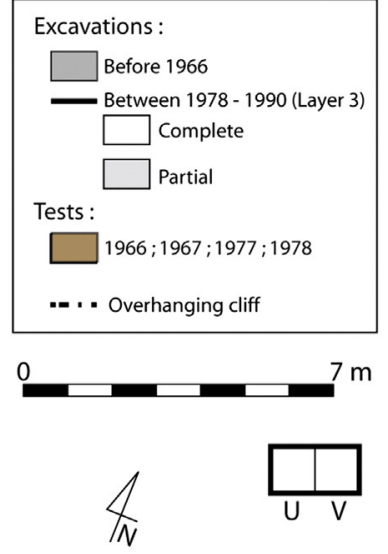

Oc. Cupillard \& S. Roué DAO:C. Leduc \& N. Carquigny 2014

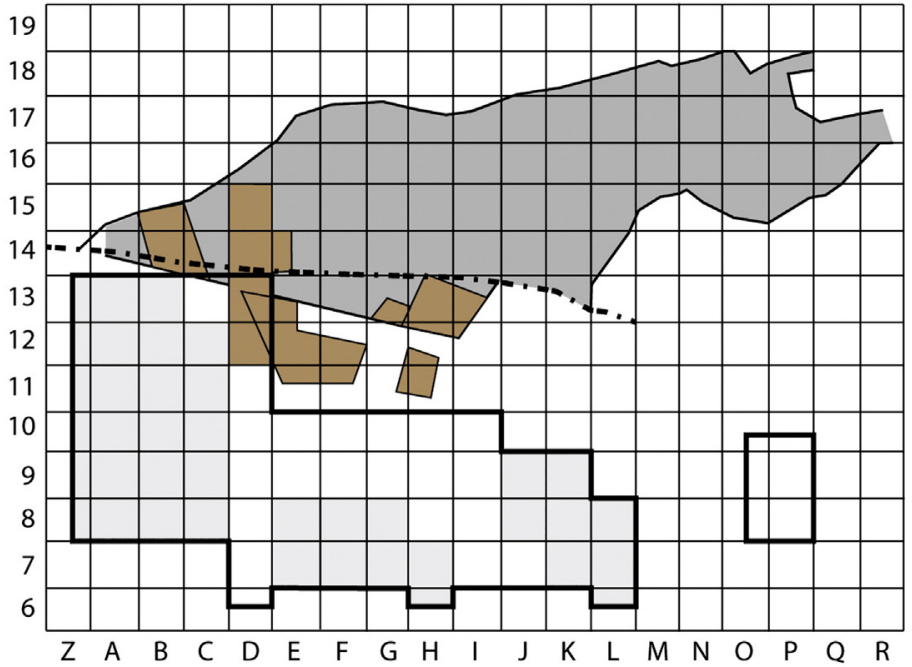

Fig. 3. Stratigraphy of "Les Cabônes" Rockshelter and map of Mesolithic layer 3. After S. Roué (2000) (@ N. Carquigny). overhanging cliff and the river. In this zone, the layer was locally disturbed to varying extents by old badger holes which were easily identified during excavation.

Overall, layer 3 yielded abundant archaeological remains (Fig. 4), including a rich and varied lithic industry with many microliths (Roué, 2000), a very large collection of mammal bones and fish bones (Frontin, 2008) as well as bone and antler tools (Cupillard, 1998b), personal ornaments (Cupillard, 1998c) and human bones (Valentin, 1998).

In layer 3 , the detailed study of a large assemblage of microliths (more than 820) indicates that the Mesolithic occupations belong to different cultural phases: the end of the Early Mesolithic (Early Mesolithic with segments) located in the lower part of the layer; the Middle Mesolithic in the main part of the layer (Sauveterrian technocomplex) and finally the Late Mesolithic which is minimal and only documented at the top of the layer (Cupillard, 1998a; Roué, 2000).

Eleven radiocarbon dates are available for layer 3, five of which are AMS dates, all of which are presented in this paper. AMS dates were obtained recently on well-identified bones of red deer, lynx and badger, but the last should be excluded as it corresponds to an intrusive Neolithic specimen (Table 1). The four other AMS radiocarbon dates on bone date the layer between 8200 and $7100 \mathrm{cal} \mathrm{BC}, 2 \sigma$. If only dates on ungulates (red deer) are considered, then the average date provides an age between 8200 and 7300 cal BC (Table 1), i.e., between the end of the Preboreal and the beginning of the Atlantic period.

The large thickness of layer 3, variation in the microlith spectrum from the base to the top of the layer, and the results of AMS radiocarbon dates indicate a cumulative archaeological unit, sensu Brochier (1999) rather than a single event. At present, the duration and frequency of the Mesolithic occupations at Les Cabônes constitute an open question subject to ongoing research. While the overall homogeneity of the lithic industry allows us to consider this layer as representative of repeated occupations by the same cultural groups during the Boreal period, the uncertainty regarding patterns and duration of occupation should be kept in mind in the discussion (see below).

\section{The material}

A former preliminary study of faunal remains was conducted immediately after excavation (Auguste, 1990). For Mesolithic layer 3, more than 4000 bone fragments were counted at that time and 2680 identified to species (Table 2). The faunal spectrum included twelve species, wild boar being the first species with 1210 identified remains (45\% of 


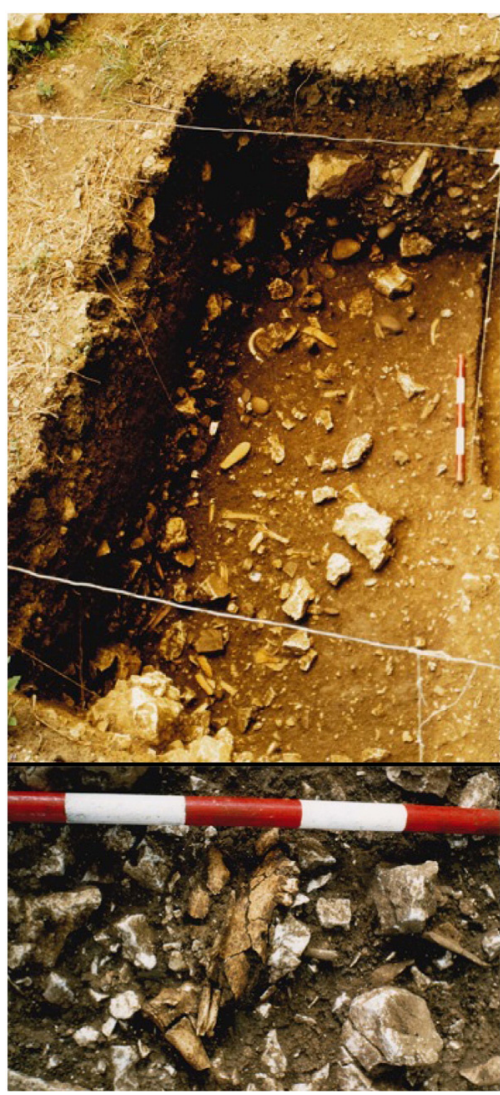

Fig. 4. Excavation of "Les Cabônes" rockshelter (1988). Detail of excavation in layer 3 with bones and wild boar tusk.

(c) C. Cupillard.

the NISP). This first result and the importance of the species in the regional Mesolithic economies motivated the present analysis centered of the wild boar hunting strategies.

The work conducted by one of the authors $(\mathrm{CL})$ complemented the initial sample studied for layer 3, increasing the number of identified wild boar remains to 2989 , thus confirming the importance of this species in the faunal spectrum, together with red deer. This faunal material is quite abundant in comparison with the other Mesolithic assemblages. Wild boar remains are present throughout layer 3, without any visible spatial organization. Like other faunal remains, they are distributed homogeneously (vertically and spatially) among the square meters excavated in layer 3. They are also very well-preserved although fragmented. Exhaustive sieving using successive several size mesh (from $10 \mathrm{~mm}$ to $1 \mathrm{~mm}$ ) resulted in the recovery of the smallest bone fragments and elements (sesamoids, deciduous teeth, etc.). Teeth $(\mathrm{N}=705)$ account for $23.6 \%$ of the wild boar remains (Table 3 ). Although complete jaws are not represented in this assemblage, portions with several teeth $(\mathrm{N}=179)$ and isolated teeth $(\mathrm{N}=526)$ are well-preserved, and include deciduous canines and incisors (Fig. 5) as well as tooth buds/germs. Such characteristics make this an important archaeofaunal assemblage to investigate hunting strategies.
Table 2

List of species and number of identified specimens from the former study conducted after excavation, by P. Auguste (1990) for layer 3.

\begin{tabular}{lrc}
\hline Taxa & NISP & \%NISP \\
\hline Wild boar (Sus scrofa scrofa) & 1210 & 45.15 \\
Red deer (Cervus elaphus) & 1039 & 38.77 \\
Roe deer (Capreolus capreolus) & 164 & 6.12 \\
Beaver (Castor fiber) & 103 & 3.84 \\
Badger (Meles meles) & 35 & 1.3 \\
Aurochs (Bos primigenius) & 34 & 1.27 \\
Fox (Vulpes vulpes) & 25 & 0.93 \\
Hare (Lepus europaeus) & 20 & 0.75 \\
Wolf (Canis lupus) & 18 & 0.67 \\
Pine marten (Martes martes) & 16 & 0.6 \\
Wild cat (Felis sylvestris) & 15 & 0.56 \\
Lynx (Lynx lynx) & 1 & 0.04 \\
Total & $\mathbf{2 6 8 0}$ & $\mathbf{1 0 0}$ \\
\hline
\end{tabular}

\section{Method}

To construct age-at-death distributions, i.e. mortality profiles, aging methods based on tooth eruption and wear stages were used, being the most reliable and precise. Estimations of age are largely conditioned by the validity of the reference data, an important point that needs to be presented prior to the analysis (see below: Section 4.1). Following the selection of reference data, specific methodological issues are discussed, such as the importance of taking into account isolated teeth and the means to reconstruct theoretical individuals.

\subsection{Modern pig referentials of tooth eruption and use-wear patterns}

Many studies have been published on tooth eruption in European and Asian pigs, both domestic (e.g., McCance et al., 1961; Higham, 1967; Silver, 1969; Habermehl, 1975) and wild (Matschke, 1967; Briedermann, 1967; Kozlo and Nikitenko, 1967; Diong, 1973; Varin, 1977; Hayashi et al., 1977; Iff, 1978; Bull and Payne, 1982; Habermehl, 1985; Genov et al., 1992; Boitani and Mattei, 1992; Rowley-Conwy, 1993; Rolett and Chiu, 1994; Baubet et al., 1994; Bridault et al., 2000; Magnell, 2006a,b; Carter and Magnell, 2007; Magnell and Carter, 2007; Anezaki, 2009; Lemoine et al., 2014) or both (Legge, 2013), that may be applied in archaeology. Data for tooth eruption in pigs may vary between different authors (e.g., Bridault et al., 2000; Genov et al., 1992). This important point was further recently synthesized in a review (Legge, 2013) showing clearly that such discrepancies reflect in part variability of tooth eruption ages between different populations of pig (wild, feral, domestic), and in part criteria selected by different authors to record tooth eruption. For instance, the M2 age range is 9 to 12 months in domestic pigs and 12 to 14 months in wild boar. Similarly, M3 eruption ages are earlier for domestic pigs than for boar. Tooth eruption is a process that may last several weeks or months between the emergence of the tooth through the bone, through the gum and its full eruption. Some authors consider the initial phase of eruption, when the tooth breaks through the gum (Matschke, 1967: 109; Magnell, 2006a), corresponding, for the molars, to the first occlusion of the anterior cusps. But others detail every stage - primary, secondary and tertiary eruption (Higham, 1967; Rowley-Conwy, 1993). Carter and Magnell (2007; Magnell and Carter, 2007) prefer to refer to tooth

Table 1

Radiocarbon dates from "Les Cabônes” rockshelter.

\begin{tabular}{|c|c|c|c|c|}
\hline Sample dated & Age BP & Cal BC, 2s & Reference lab. & Reference \\
\hline Bone, red deer & $8840 \pm 60$ & $8219-7749$ & GrA-21529 & Drucker et al. (2008) \\
\hline Bone, red deer & $8570 \pm 60$ & $7724-7582$ & GrA-21524 & Drucker et al. (2008) \\
\hline Bone, red deer & $8380 \pm 45$ & $7542-7341$ & GrA-23149 & Drucker et al. (2008) \\
\hline Bone, lynx & $8160 \pm 05$ & $7300-7061$ & GrA-38027 & Cupillard et al. (in press) \\
\hline Bone, badger & $4470 \pm 35$ & - & GrA-38025 & Cupillard (2008) \\
\hline
\end{tabular}


Table 3

Distribution of wild boar teeth in age groups from "Les Cabônes" rockshelter.

\begin{tabular}{|c|c|c|c|c|c|c|c|c|c|}
\hline \multirow[t]{2}{*}{ Age groups } & \multicolumn{3}{|c|}{ Isolated teeth } & \multirow{2}{*}{$\begin{array}{l}\text { Mandible or } \\
\text { Maxilar fgts }\end{array}$} & \multirow{2}{*}{$\begin{array}{l}\text { Total of tooth } \\
\text { remains }\end{array}$} & \multirow{2}{*}{$\begin{array}{l}\% \text { of isolated } \\
\text { teeth }\end{array}$} & \multirow{2}{*}{$\begin{array}{l}\text { MNI without isolated } \\
\text { cheek \& front teeth }\end{array}$} & \multirow{2}{*}{$\begin{array}{l}\text { MNI with isolated } \\
\text { cheek teeth }\end{array}$} & \multirow{2}{*}{$\begin{array}{l}\text { MNI all } \\
\text { teeth }\end{array}$} \\
\hline & Cheek & Front & Total & & & & & & \\
\hline 0-6 months & 27 & 89 & 116 & 11 & 127 & 91.3 & 4 & 9 & 11 \\
\hline 6-12 months & 20 & 101 & 121 & 43 & 164 & 73.8 & 6 & 7 & 12 \\
\hline $12-18$ months & 18 & 79 & 97 & 15 & 112 & 86.6 & 2 & 5 & 6 \\
\hline 18-24 months & 5 & 36 & 41 & 13 & 54 & 75.9 & 3 & 3 & 3 \\
\hline 24-36 months & 10 & 30 & 40 & 14 & 54 & 74.1 & 2 & 3 & 3 \\
\hline $3-5$ years & 14 & 41 & 55 & 37 & 92 & 59.8 & 7 & 9 & 9 \\
\hline 5-7 years & 5 & 36 & 41 & 42 & 83 & 49.4 & 4 & 4 & 4 \\
\hline $7-10$ years & 6 & 9 & 15 & 4 & 19 & 78.9 & 1 & 1 & 2 \\
\hline Total & 105 & 421 & 526 & 179 & 705 & 74.6 & 29 & 41 & 50 \\
\hline Total \% & 20 & 80 & 100 & & & & & & \\
\hline
\end{tabular}

development, i.e., stages from crown formation into the jaw to root enclosure. Such a method is particularly useful to provide precise eruption stages for isolated teeth. Particularly striking is the case of M3, a three cusp tooth: 3 months when the start of the process is only considered (Matschke, 1967) or up to 17 months, when full eruption is taken into account (Magnell, 2006a,b; Carter and Magnell, 2007; Magnell and Carter, 2007).

Finally, G.H. Matschke's referential stands as the most complete, based on a large and detailed data-set, dealing with about 200 individuals of different ages, progeny of wild boars captured in Europe and reared in Tennessee (Matschke, 1967). Moreover, this is the only referential in which absolute eruption age (with mean and range) is given for every upper and lower tooth. It has been tested and largely confirmed by application to modern and archaeological samples (Baubet, 1998; Bridault et al., 2000; Magnell, 2005, 2006a,b; Carter and Magnell, 2007; Magnell and Carter, 2007; Legge, 2013; Lemoine et al., 2014).

Based on radiographs of the lower jaws of wild boar and crossbred pigs, Magnell and Carter's study confirms the eruption stages given by Matschke and clarifies the timing for M3 eruption: mesial cusp between 19 and 24 months; distal cusp between 25 and 36 months (Carter and Magnell, 2007). Both referentials (Matschke, 1967; Carter and Magnell, 2007) were used in the present work (Table 4).

Aging from tooth wear patterns is appropriate for adult animals with full permanent dentition, i.e. when M3 is fully erupted, over 36 months (Carter and Magnell, 2007). Data-sets dealing with use-wear for pigs are, however, less numerous (Kozlo and Nikitenko, 1967; Higham, 1967; Habermehl, 1975; Varin, 1977; Iff, 1978; Grant, 1982; Briedermann, 1967; Rowley-Conwy, 1993; Rolett and Chiu, 1994; Horard-Herbin, 1997; Wright et al., 2014). Information on the size of
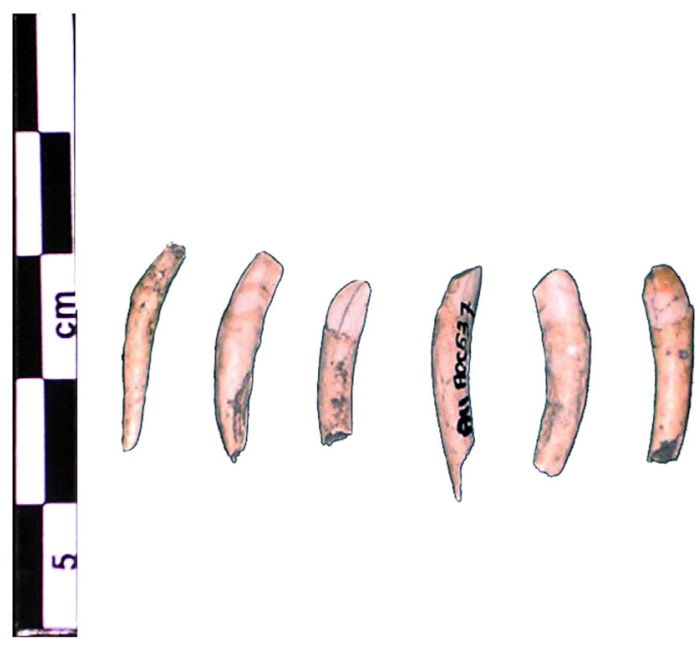

Fig. 5. Decidual canines from very young wild boar (0-6 months old). the corpus and the population studied are often lacking and in the main studies, some age groups are less represented, specifically older groups.

Grant's method (Grant, 1982), based on tooth wear coding, is widely used in archaeozoological studies. This provides a technique to accurately record dental wear stages for lower cheek teeth in pig, although it does not allow estimation of absolute ages. Magnell (2006a) tested this method on present-day wild and crossbred boar from five different populations (Poland, Germany and Sweden), demonstrating a strong correlation (regression line and scatterplot of MWS versus age) between Grant's wear stages and age, at least for individuals up to 36 months old. Observing early use-wear patterns for wild boar of known age, with dentition that is not fully erupted, he noted low asymmetry in wear patterns on left and right mandibles of single individuals, as well as little variation between individuals of the same age stage up to 36 months, a fact recently confirmed (Lemoine et al., 2014). But for older individuals, tooth wear patterns observed in present-day wild boar over three years of age can exhibit marked variation between individuals in the same age class and between different populations (Habermehl, 1985; Grant, 1978, 1982; Bull and Payne, 1982), mostly dependent on feeding habits (McCance et al., 1961; Grant, 1978, 1982). However, as mentioned above, this pattern is not clearly detailed as older individuals are often less represented in referential data. Estimation of age in adult animals is thus less precise (2 to 3 age classes) and more difficult, especially when jaw remains are fragmented.

In the present work, the wear-pattern for each isolated tooth or mandible fragment of adult animals was recorded, based on Grant's

Table 4

Referential data for wild boar tooth eruption stages, used in the present study. Eruption stages for upper and lower teeth, from G.H. Matschke (1967). Adjustment of third molar eruption according to Magnell and Carter (2007; Carter and Magnell, 2007).

\begin{tabular}{lll}
\hline Teeth & $\begin{array}{l}\text { Eruption time } \\
\text { Upper jaw }\end{array}$ & $\begin{array}{l}\text { Eruption time } \\
\text { Lower jaw }\end{array}$ \\
\hline DI1 & $7-22$ days & $11-20$ days \\
DI2 & $2-3.8$ months & $2-3$ months \\
DI3 & In utero & In utero \\
I1 & $12.3-15$ months & $12.5-14.5$ months \\
I2 & $21.4-26$ months & $18.4-22$ months \\
I3 & $7.3-11.7$ months & $7.5-9.2$ months \\
Dc & In utero & In utero \\
C & $7-11.4$ months & $2-3.3$ months \\
DP2 & $1.6-2.6$ months & 23 days-1 months \\
DP3 & $11-18$ days & 11 days-20 days \\
DP4 & $1.3-1.9$ months & $15-17$ months \\
P2 & $16-17.1$ months & $14-16$ months \\
P3 & $15-16.2$ months & $14-17.7$ months \\
P4 & $14-18.4$ months & $5.2-6$ months \\
M1 & $5.3-6.3$ months & $11.8-13.6$ months \\
M2 & $12-13.8$ months & $19-24$ months (mesial cusps) \\
M3 & $25.6-32.4$ months & $25-36$ months (distal cusps) \\
\end{tabular}


method and assigned to age ranges of 3-5 years; $5-7$ years and 710 years following various publications (Habermehl, 1975; Varin, 1977; Iff, 1978). Life expectancy of modern wild boar is between 10 and 15 years (Etienne, 2003; Varin, 1980; Habermehl, 1975). Here, a 10 -year life span was used, as no teeth remains with extreme wear were recorded in the assemblage. In a recent article, Lemoine et al. (2014) devised a scoring system for individual teeth from prior to formation through heaviest wear, adapted from Grant's wear stages and based on clear and efficient recording rules. We tested this system on a Ranchot subsample of adult mandibles of different ages. The results show a generally good match in the estimate of ages between this system and the one we initially used. Slight discrepancies can nonetheless be noted: our 5-7 year age group corresponds to the 4.5-6 year age group in the Lemoine system; and individuals we assigned to the 7-10 year old group fall in the 7-8 year age group in the Lemoine system, thus confirming the absence of very old hunted animals at Ranchot.

Finally, age attribution for teeth from Les Cabônes was based on Matschke's (1967) and Carter and Magnell's (2007) eruption stages, and correspondence between detailed use-wear patterns (Grant, 1982) and defined age groups (Habermehl, 1975; Varin, 1977; Iff, 1978).

\subsection{The importance of including isolated teeth}

As is the case here, isolated teeth are often predominant among archaeological assemblages, but are rarely included in age attribution studies (Rolett and Chiu, 1994; Magnell, 2005, 2006a,b; Haber, 2007; Magnell and Carter, 2007). However, they ensure better representation, notably of very young individuals (from birth to 12 months) whose jaws are more sensitive to breakage and destruction. Including or excluding isolated teeth from a study may significantly modify mortality profiles and, consequently, interpretation of hunting strategies, making it a crucial methodological issue. In a recent study, mortality profiles were reconstructed for wild boar from three different archaeological samples, using different samples of teeth, including or not maxillary tooth rows or loose teeth. While general profiles remain the same, it appears that using maxillary remains provides better representation of adult individuals while the use of loose teeth is essential for juvenile individuals (Lemoine et al., 2014). In the present assemblage, isolated teeth are primarily front teeth $(80 \%)$ while cheek teeth are mainly premolars (Table 2). Isolated deciduous teeth are quite common and this is especially important to consider as juvenile individuals are represented by fewer teeth than adults and their teeth are more fragile (Munson and Garniewicz, 2003).

\subsection{Searching for individuals}

The reconstruction of age-at-death distributions (mortality profiles) in the present study begins with the detailed examination of each toothmandibular and maxillary remain and their precise identification, in order to sort them into upper/lower and right/left remains. Second, the eruption/wear stage is recorded for each dental remain (either isolated or set in the jaws), following the referential data outlined above. Third, we assign age ranges to these remains, with larger age ranges for isolated permanent worn teeth. Fourth, we attempt to refit mandible or maxilla fragments and isolated upper and lower teeth as much as possible. Fifth, we match left and right-lower and upper elements of the same age ranges, based on idiosyncratic patterns of wear and sexing, in order to reduce double counting and estimate the minimum number of individuals. Sexing the remains by the morphology of the canines as well as the socket when the tooth is missing (Schmid, 1972; Mayer and Brisbin Lehr, 1988) refines the identification of the individuals. The estimated Minimal Number of Individuals, here based on age (dental development and wear), sex, size differences, patterns of wear, pairing (left and right halves) and matching (upper and lower), is greater than the MNE (complete jaws) determined with consideration of type of teeth and side only. The MNI is thus closer to the initial number of individuals that contributed to the assemblage (Poplin, 1976a,b). Finally, the construction of mortality profiles may be realized by including the number of teeth or the number of individuals per age class.

\section{The wild boar age mortality profile for Les Cabônes, layer 3}

A total of 705 dental elements (NISP) and fifty individuals have been distributed into eight age classes (Table 3; Figs. 5-7).

- 0 to 6 months: NISP $=127$ dental remains, $\mathrm{MNI}=11$. Two are perinatal individuals, whose deciduous premolars exhibit very slight wear and the presence of a first molar bud. Five individuals with unerupted $\mathrm{M} 1$ (in crypt), are 2-4 months old.

- 6 to 12 months: NISP $=164$, MNI $=12$. These individuals were mostly estimated by upper teeth. 7 individuals with unworn M1 can be aged between 6 and 7 months.

- 12 to 18 months: NISP $=112$, MNI $=6$. Most of these individuals $(\mathrm{n}=5)$ have unworn upper M2 with incomplete roots and permanent premolar buds and can be aged between 12 and 15 months.

- 18 to 24 months: NISP $=54, \mathrm{MNI}=3$.

- 24 to 36 months: NISP $=54, \mathrm{MNI}=3-2$ females and 1 male. This age group is the first with individuals having complete permanent dentition. Most have all their teeth in wear, except for the youngest one with M3 in early erupting stage.

- 3 to 5 years: NISP $=92$, MNI $=9$, including 3 females and 1 male.

- 5 to 7 years: $\mathrm{NISP}=83, \mathrm{MNI}=4$, including 2 females and 2 males.

- 7 to 10 years: NISP $=19$, MNI $=2$ males. These are the oldest individuals of the assemblage with all teeth worn.

Fig. 8 shows a graphic representation of the age-at-death frequency distribution, based on corrected data (Table 5). In the histogram, the frequencies of each age class are proportional to the area of each bin and are calculated by dividing the relative frequency by the bin width of each age class (Brochier, 2013).

As stated above, isolated teeth were included in the analysis leading to the mortality profile (Fig. 8). Exclusion of such remains lead, as expected (Lemoine et al., 2014), to the underrepresentation of younger individuals, as shown in Fig. 9. It is particularly striking here for the 0-6 months and 12-18 months groups, for which the numbers of individuals more than doubled ( 4 to 9 and 2 to 5 , respectively) as younger age groups are documented predominantly by isolated teeth: $91.3 \%$ for 0-6 months; $73.8 \%$ for 6 -12 months (Table 3; Figs. 8 \& 9). An increasing representation of individuals can also be observed regarding individuals up to 3 years, thus including the young adult age groups. After the age of five years, the inclusion of isolated teeth no longer increases the number of individuals.

Eventually, all age groups are present in the wild boar mortality profile at Les Cabônes (Fig. 8), but in different proportions. The predominance of juvenile individuals should be noted: $64 \%$ of the individuals (32 individuals) are less than 2 years old. The youngest age groups are particularly well-represented: $22 \%$ of the hunted wild boar are less than 6 months old $(\mathrm{MNI}=11), 24 \%$ from 6 months to 12 months old $(\mathrm{MNI}=12)$ and $12 \%$ from 12 to 18 months old $(\mathrm{MNI}=6)$. Adults over two years old are present but in lower proportions (36\% of the individuals) and are mostly young adults from 2 to 5 years old. Only two individuals older than 7 years old have been identified, based on third molar use-wear patterns. For these, both third molars are not deeply worn, referring to Grant's stages $e / f$ and $g$, probably indicating a position at the beginning of this last age group.

As the main goal of the original study (Leduc, 2005) focused on mortality profiles, the entire assemblage of wild boar teeth was studied, making it possible as well to reconstruct hunting strategies. 

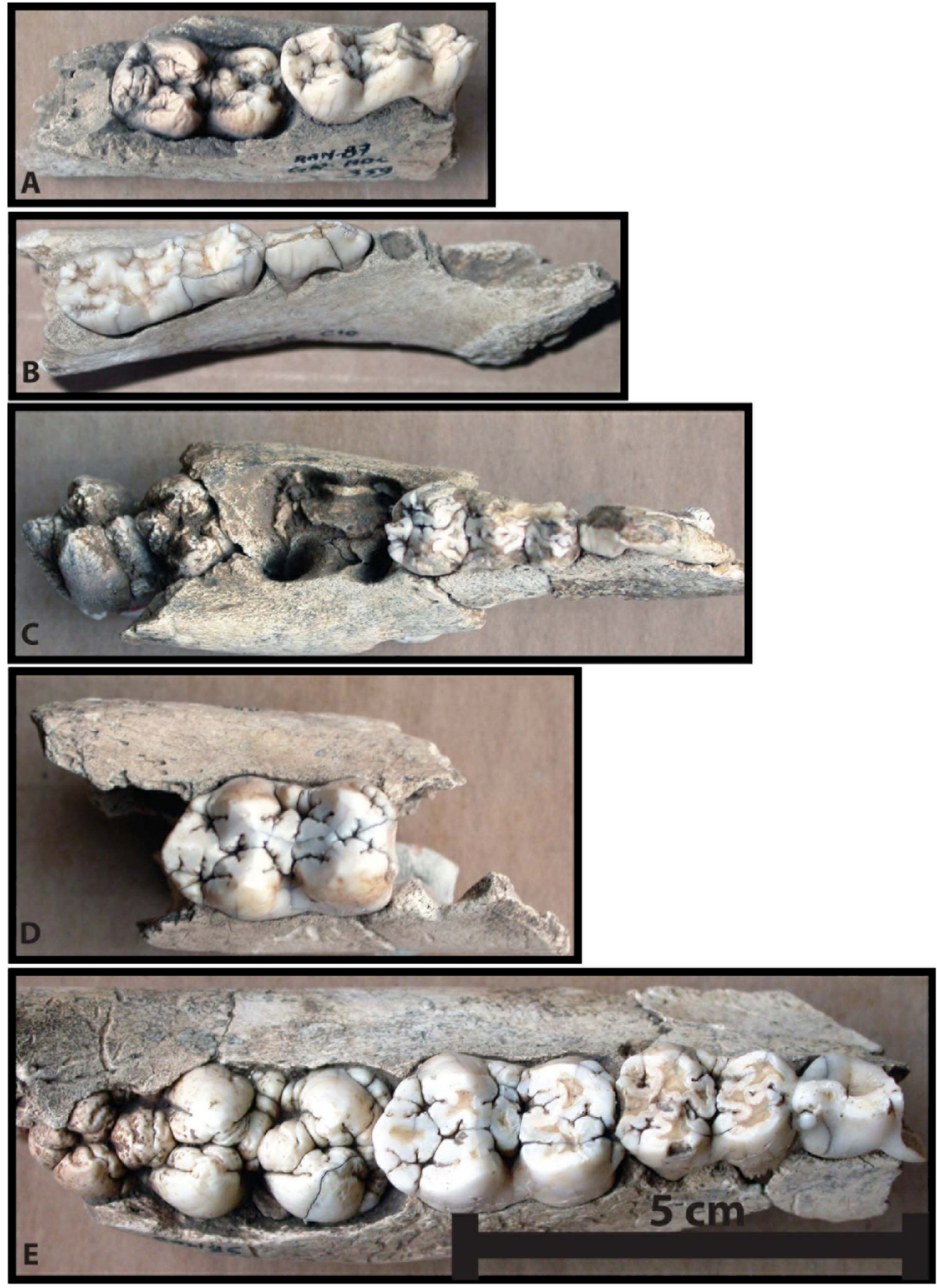

Fig. 6. Example of teeth from "Les Cabônes" rockshelter distributed in different age groups: A \& B: 0-6 months; C: 6-12 months; D: 18-24 months; E: 24-36 months. (C) A. Bridault.

\section{Discussion}

The duration and frequency of the Mesolithic occupation (layer 3) at Les Cabônes are not known for certain and may be the result of repeated and cumulative occupations. In this perspective, establishing the wild boar hunting season(s) is relevant to clarify the period(s) and/or rhythm of site occupation. This is, however, quite difficult to ascertain. First, present-day wild boar birth periods in France range from January to September, even if the majority of births occur between March and June (Lauwerier, 1983; Mauget et al., 1984; Boitani et al., 1995a,b). Moreover, two birth patterns, per year, can occur in a single population: a uni-modal type (one litter), with females giving birth mostly from March to June and a bi-modal type (two litters), showing a first birth peak from January to March and a second peak from August to September (Mauget et al., 1984; Boitani et al., 1995a,b). Such variability depends on several parameters: geographic, climatic and above all food availability and good conditions increasing farrows (Lauwerier, 1983;
Mauget et al., 1984; Baubet, 1998; Pépin, 1991; Santos et al., 2006). Consequently, considering the youngest individuals of the assemblage with very precise ages, up to 7 months (cf supra 5: five individuals aged between 2 and 4 months, and seven individuals between 6 and 7 months) and the two farrowing patterns to infer seasons of mortality, piglets could have been hunted at many different times of the year. Following the uni-modal type, hunting episodes could have occurred from May to October (minimum) or from March to January (maximum). The bi-modal type could reflect hunting episodes in March (in accordance with all individuals), but this could rather also reflect hunting episodes almost all year-round, from January to October (Fig. 10). It is therefore not possible to clearly resolve the question of seasonality of occupation at Les Cabônes. Very strict seasonal hunting episodes cannot be excluded, and possibly separated by long times without occupation, although several hunting seasons are quite probable based on very precise young ages, and the presence of other age groups (12-18 and 18-24 months). Admitting this, and considering the corpus as representative of hunting 

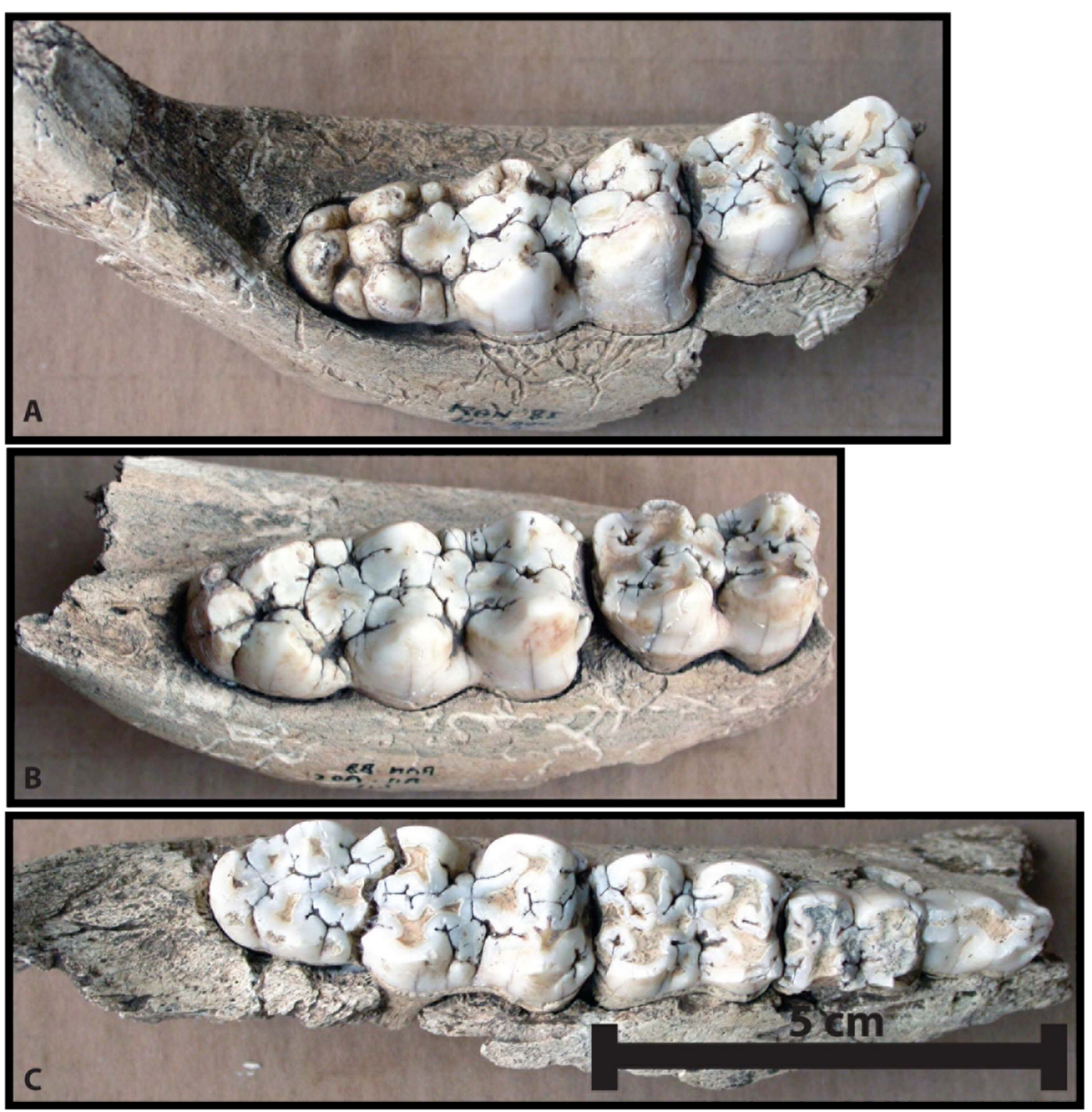

Fig. 7. Example of teeth from "Les Cabônes" rockshelter distributed in different age groups: A: 3-4 years; B: 4-5 years; C: 6-7 years. (c) A. Bridault.

strategies developed by cohesive Mesolithic groups, how can these strategies be described?

The high proportion of piglets (22\%, less than 6 months old), juveniles (24\%, 6-12 months) and individuals from 1 to 2 years old (18\%) in addition to young adult females (7 individuals - Table 3; Fig. 8), indicates that typically sounders, i.e., sows and their offspring, were regularly hunted. Sounders form social groups of 10-20 individuals (Vassant et al., 2010) led by an old matriarch. They include barren sows and mothers with juveniles from the previous litter. Subadult males are driven out of the sounder at the age of 9-13 months (Bouldoire and Vassant, 1989: 88-89) and form loose groups, while adult and elderly males tend to be solitary most of the year. Sounders form a stable social group outside the breeding season. They move around in a more circumscribed area than solitary males, following paths (Bouldoire and Vassant, 1989; Vassant et al., 2010) mostly during the night (Mauget, 1984); consequently their encounter rate is higher. They are also easier to locate as they are noisy. Hunting sounders also offers the advantage of killing several animals at the same time. But due to the high proportion of hunted juveniles at Ranchot, which are less bulky than adults, such hunting was not the most effective in terms of net returns. However, it cannot be excluded that the occupants of the rockshelter also hunted solitary males, although occasionally, as adult males have been identified ( 5 individuals over 3 years old - Table 2; Fig. 8). Hunting adult males involves different tactics as boars are more difficult to track and can be dangerous. While time and pursuit costs may be higher and hunts riskier, males provide the highest caloric return. But other goals, such as the acquisition of tusks, may account for hunted males. Indeed, some tusk fragments found on the site are most likely fragments of tools. One has longitudinal flaking scars and the occlusal surface scraping marks (Fig. 11). Another one has scraping marks and a polished surface. Tools made from wild boar tusks are known from this geographic area during the Mesolithic, at La Baume d'Ogens (Vaud canton, Switzerland) and Birsmatten-Basisgrotte (Bern canton, Switzerland) (David, 2000) and during the Mesolithic in general (Marquebielle, 2014).

The results from Les Cabônes layer 3, based on a large sample, confirm the hunting of sounders as previously pointed out at the site of Rochedane (Doubs), located in the same region (Bridault, 1993, 1994). At Rochedane, boar exploitation was coupled with selective red deer hunting, targeting adults, mostly stags, which was interpreted as a high risk strategy maximizing net returns (ibid.). Thus, the acquisition of the two key game species was based on complementary strategies. This may be the case at Les Cabônes, but results for red deer exploitation are not yet available. Nonetheless, it is clear that the acquisition of wild boar at Les Cabônes 3 was based on different hunting episodes targeting different social groups and/or individuals. Sounder hunting ensures a steady food supply (including tender meat from piglets). Hunting of occasional solitary males would certainly provide a greater quantity of meat and grease per capita, but also ivory. Tusks were likely items sought-after for their technical properties and/or because they would be socially valued. Such a strategy would have also involved different hunting tactics (approach, beating, ambush, etc.).

\section{Conclusion}

The meticulous recovery techniques used during excavation and the good preservation of the faunal material from layer 3 of Les Cabônes rockshelter offered the opportunity to analyze a large sample of boar 

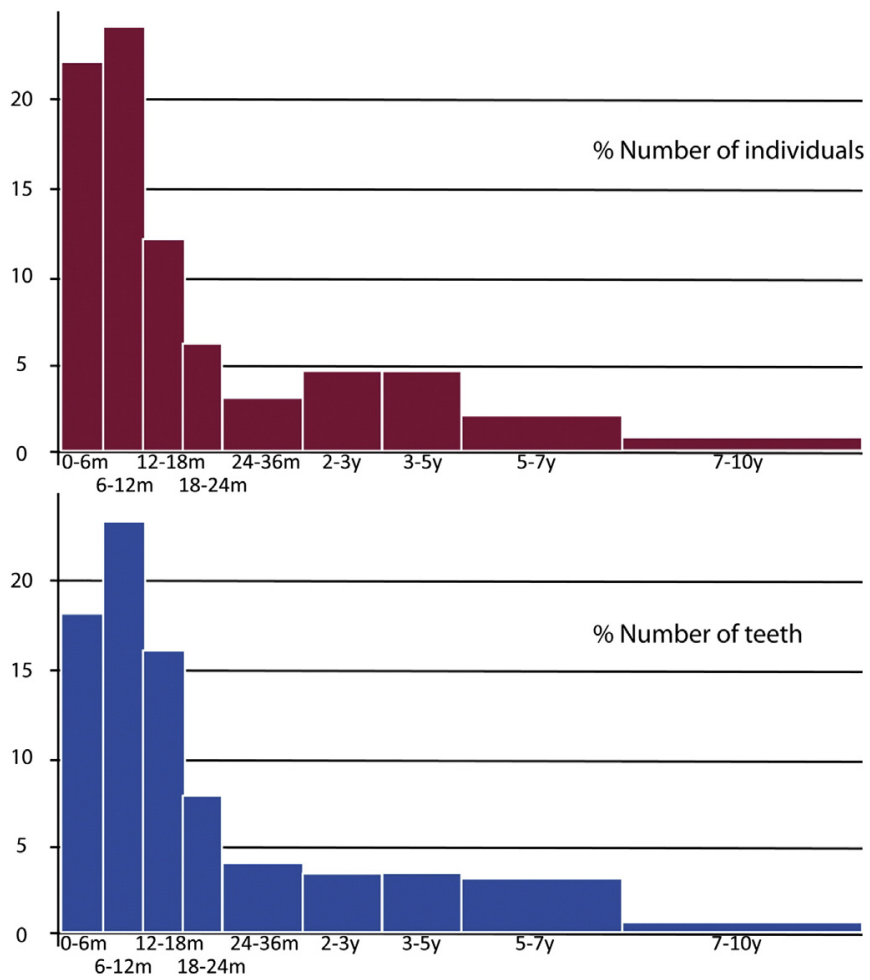

Fig. 8. Mortality profile for wild boar at "Les Cabônes" rockshelter (MNI = 50; number of teeth $=705$ ).

remains to reconstruct the hunting strategies for one of the key resources during the Mesolithic period.

Boar populations were likely abundant in the region during the period of site occupation (8200-7300 cal BC). Preying on sounders, the main social group, would have provided a regular source of animal protein and grease, while occasional male boar hunts would have been an activity oriented rather towards the acquisition of valued items.

If this study focused on the analysis of teeth remains, we were also able to register in details a large sample of more than the two-thirds of wild boar post-cranial remains from Les Cabônes layer 3 (NISP = $844, \mathrm{MNE}=680, \mathrm{MNI}=16$ ). This sample was tested in order to get some preliminary information regarding carcass processing. These
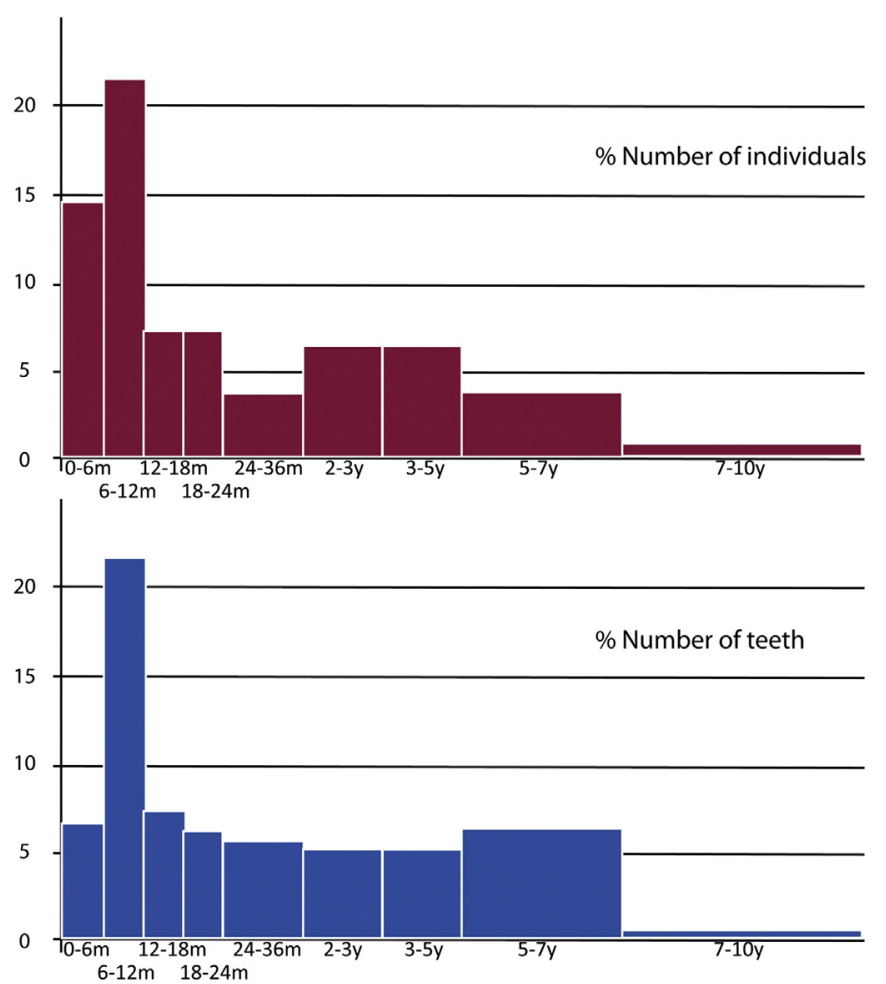

Fig. 9. Mortality profile for wild boar at "Les Cabônes" rockshelter, excluding cheek and front isolated teeth $(\mathrm{MNI}=27$; number of teeth $=149)$.

preliminary data suggest that wild boar may have been brought onto the site on a regular basis (cf. formation process of layer 3 ) as complete or nearly complete carcasses to be butchered (as indicated by the high number of cutmarks) and probably consumed onsite. Wild boar may have been brought onto the site on a regular basis (cf. formation process of layer 3) as complete or nearly complete carcasses to be butchered (as indicated by the high number of cutmarks) and probably consumed onsite. The site occupation corresponding to layer 3 could have lasted more than one season and functioned as a base camp (Cupillard, 2002; Cupillard and Perrenoud-Cupillard, 2003).

The relationship between site function and/or duration of occupation and wild boar strategies has been discussed in other Mesolithic

Table 5

Corrected distribution of wild boar teeth in age groups from "Les Cabônes" rockshelter, according to age group size.

\begin{tabular}{|c|c|c|c|c|c|c|c|c|c|}
\hline Age groups & $\mathrm{N}$ teeth & MNI & $\% \mathrm{~N}$ teeth & $\% \mathrm{MNI}$ & Corrected age (in years) & Corrected $\mathrm{N}$ teeth & Corrected MNI & Corrected $\mathrm{N}$ teeth \% & Corrected MNI \% \\
\hline 0-6 months & 127 & 11 & 18.0 & 22 & $0-0.5$ & 127 & 11 & 18 & 22 \\
\hline 6-12 months & 164 & 12 & 23.3 & 24 & $0.5-1$ & 164 & 12 & 23.3 & 24 \\
\hline 12-18 months & 112 & 6 & 15.9 & 12 & $1-1.5$ & 112 & 6 & 15.9 & 12 \\
\hline 18-24 months & 54 & 3 & 7.7 & 6 & $1.5-2$ & 54 & 3 & 7.7 & 6 \\
\hline \multirow[t]{2}{*}{$24-36$ months } & 54 & 3 & 7.7 & 6 & $2-2.5$ & 27 & 1.5 & 3.8 & 3 \\
\hline & & & & & $2.5-3$ & 27 & 1.5 & 3.8 & 3 \\
\hline \multirow[t]{4}{*}{$3-5$ years } & 92 & 9 & 13.0 & 18 & $3-3.5$ & 23 & 2.25 & 3.3 & 4.5 \\
\hline & & & & & $3.5-4$ & 23 & 2.25 & 3.3 & 4.5 \\
\hline & & & & & $4-4.5$ & 23 & 2.25 & 3.3 & 4.5 \\
\hline & & & & & $4.5-5$ & 23 & 2.25 & 3.3 & 4.5 \\
\hline \multirow[t]{4}{*}{$5-7$ years } & 83 & 4 & 11.8 & 8 & $5-5.5$ & 20.75 & 1 & 2.9 & 2 \\
\hline & & & & & $5.5-6$ & 20.75 & 1 & 2.9 & 2 \\
\hline & & & & & $6-6.5$ & 20.75 & 1 & 2.9 & 2 \\
\hline & & & & & $6.5-7$ & 20.75 & 1 & 2.9 & 2 \\
\hline \multirow[t]{6}{*}{$7-10$ years } & 19 & 2 & 2.7 & 4 & $7-7.5$ & 3.17 & 0.3 & 0.4 & 0.67 \\
\hline & & & & & $7.5-8$ & 3.17 & 0.3 & 0.4 & 0.67 \\
\hline & & & & & $8-8.5$ & 3.17 & 0.3 & 0.4 & 0.67 \\
\hline & & & & & $8.5-9$ & 3.17 & 0.3 & 0.4 & 0.67 \\
\hline & & & & & $9-9.5$ & 3.17 & 0.3 & 0.4 & 0.67 \\
\hline & & & & & $9.5-10$ & 3.17 & 0.3 & 0.4 & 0.67 \\
\hline Total & 705 & 50 & 100 & 100 & - & 705 & 50 & 100 & 100 \\
\hline
\end{tabular}




\begin{tabular}{|c|c|c|c|c|c|c|c|c|c|c|c|c|c|c|}
\hline Taxa & Age & $\mathrm{N}$ ind. & Jan. & Feb. & Mar. & April & May & June & July & Aug. & Sept. & Oct. & Nov. & Dec. \\
\hline \multirow{4}{*}{$\begin{array}{l}\text { Uni-modal } \\
\text { type }\end{array}$} & \multicolumn{2}{|c|}{ Birth time } & & & \multicolumn{4}{|c|}{ Birth } & & & & & & \\
\hline & perinatal & 2 & & & & & & & & & & & & \\
\hline & 2-4 months & 5 & & & & & & & & & & & & \\
\hline & 6-7 months & 7 & & & & & & & & & & & & \\
\hline \multirow{4}{*}{$\begin{array}{c}\text { Bi-modal } \\
\text { type }\end{array}$} & \multicolumn{2}{|c|}{ Birth time } & \multirow{3}{*}{\multicolumn{2}{|c|}{$\overline{\text { Birth }}$}} & & & & & & \multirow{2}{*}{\multicolumn{2}{|c|}{ Birth }} & & & \\
\hline & perinatal & 2 & & & & & & & & & & & & \\
\hline & 2-4 months & 5 & & & & & & & & & & & & \\
\hline & 6-7 months & 7 & & & & & & & & & & & & \\
\hline
\end{tabular}

Fig. 10. Seasonality data from young wild boars at "Les Cabônes" rockshelter, according to different birth period hypotheses.

contexts, notably from Scandinavian sites. A recent examination of the Mullerup (Denmark) assemblage, interpreted as a base camp attributed to the Maglemose culture, also revealed such hunting strategies targeting sounders and mostly juveniles similar to those observed at Les Cabônes (Leduc, 2010, 2013). Strategies targeting mostly juveniles, "a prey selection that ensures a maximal long-term harvest and can be associated with larger base camp," are also described at Ringsjöholm and Tågerup in Sweden (Magnell, 2006b: 95). In contrast, at sites also interpreted as hunting camps, Ageröd I:HC and Bredasten (Sweden), prey selection was made within sounders, avoiding very young individuals in order to "optimiz[e] the short-term return rates" (Magnell, 2005, 2006b: 94).

The same may be valid in geographically closer contexts, such as open-air sites from the Paris and Oise area dated to the same chronological period (Leduc et al., 2013; Ducrocq et al., 2008, 2014) with small faunal assemblages (ca 100 identified remains) dominated by wild boar. At these sites, hunters preyed on groups of females with subadults. The absence of very young individuals could reflect similar strategies to those observed at Ageröd I:HC and Bredasten (Magnell, 2005, 2006b), but, in these cases, taphonomic loss cannot be excluded, as the preservation of faunal remains is low (Leduc et al., 2013; Ducrocq et al., 2008, 2014).

Adult males were also killed, most likely during distinct hunting episodes and the use of tusks as tools is documented. However, occupation patterns at these sites are still in debate. At Paris-rue Henry-Farman, it has been concluded that each locus may have for the most part resulted from successive and probably short term (seasonal) occupations, each locus an independent event. The evidence of incomplete carcasses and incomplete butchering "chaînes opératoires" in these sites argues in favor of this interpretation. From this point of view, wild boar exploitation patterns at Les Cabônes, in situ exploitation of complete carcasses, might refer to longer occupations. The site might have functioned as a

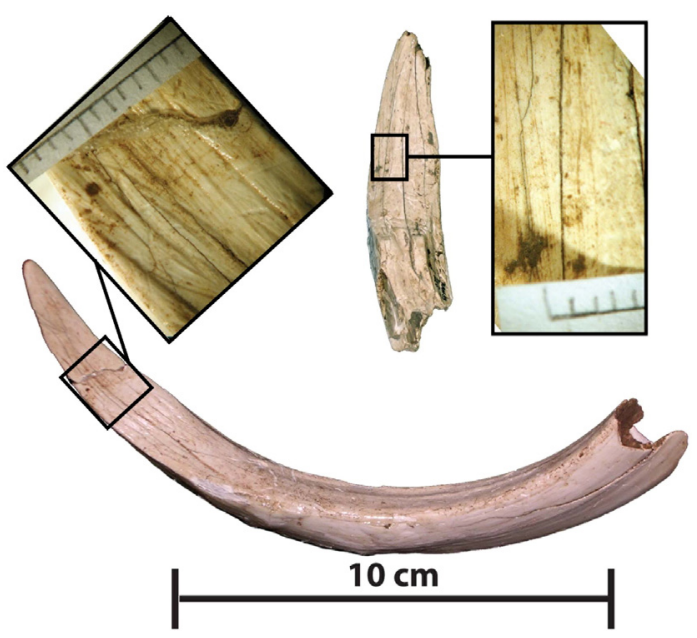

Fig. 11. Wild boar tusks showing scraping marks on their occlusal surfaces. (c) C. Leduc. base camp (Cupillard, 2002; Cupillard and Perrenoud-Cupillard, 2003; Crotti and Cupillard, 2013) as also suggested by the abundance and diversity of archaeological remains, i.e. microliths, lithic tools, bone tools, personal ornaments (e.g. red deer canines), and complete lithic chaînes opératoires. While such a connection exists between site function, occupation cycle and wild boar hunting and exploitation strategies would appear to be a promising avenue of research, such a hypothesis should be qualified, mostly considering the representativeness of faunal assemblages due to taphonomic discrepancies and cumulative or eroded occupations.

\section{Acknowledgments}

Financial support for the excavation of the Les Cabônes rockshelter (1978 to 1989) and for AMS radiocarbon dates (2005 to 2008) was provided by the French Ministère de la Culture et de la Communication (Sous Direction de l'Archéologie) under different research programs. We are very grateful to the Mayor of Ranchot for having given us permission to carry out the archaeological excavation of the Les Cabônes rockshelter, Rebecca Miller for English corrections to the manuscript and Nicolas Carquigny for his help in redrawing Fig. 4. We are grateful to the anonymous reviewers for their helpful comments.

\section{References}

Aimé, G., 1993. Les Abris sous Roche de Bavans (Doubs). Mémoire de la Société d'Agriculture, Lettres, Sciences et Arts de la Haute SaôneArchéologie $n^{\circ} 3$.

Anezaki, T., 2009. Estimating age at death in Jomon Japanese wild boar (Sus scrofa leucomystax) based on the timing of molar eruption in recent comparative samples. Mamm. Study 34, 53-63.

Auguste, P., 1990. L'apport des vestiges osseux de Ranchot (Jura), Du lard ou du cochon. Approches archéologique et ethnologique de l'histoire de l'alimentation. Actes des Séminaires publics d'archéologie de Besançon, 1988-1989. Centre Régional de Documentation Archéologique, Besançon, pp. 28-31.

Baubet, E., 1998. Biologie du sanglier en montagne, biodémographie, occupation de l'espace et régime alimentaire. UMR C.N.R.S. Biométrie, Génétique et Biologie des Populations. Université Claude Bernard-Lyon 1.

Baubet, E., Brandt, S., Jullien, J.M., Vassant, J., 1994. Valeur de l'examen de la denture pour la détermination de l'âge chez le sanglier (Sus scrofa). Gibier sauvage, Game Wildlifepp. 119-132.

Bignon-Lau, O., Coudret, P., Fagnart, J.-P., Souffi, B., 2013. Données préliminaires sur l'organisation spatiale des vestiges mésolithiques du locus 295 du gisement de Saleux (Somme): l'apport de la faune. In: Valentin, B., Souffi, B., Ducrocq, T., Fagnart, J.-P. Séara, F., Verjux, C. (Eds.), Palethnographie du Mésolithique: recherches sur les habitats de plein air entre Loire et Neckar/Mesolithic Palethnography: Researchs on open-air campsites from the river Loire to the Neckar, Actes de la table ronde internationale de Paris, 26 et 27 Novembre 2010. Société préhistorique française, Paris, pp. 169-188.

Boitani, L., Mattei, L., 1992. Ageing wild boar (Sus scrofa L.) by tooth eruption. In: Spitz, F., Janeau, G., Gonzalez, G., Aulagnier, S. (Eds.), Ongulés/Ungulates. S.F.E.P.M.-I.R.G.M., Paris-Toulouse, pp. 399-402.

Boitani, L., Trapanese, P., Mattei, L., 1995a. Demographic patterns of a wild boar (Sus scrofa, L.) population in Tuscany, Italy Ibex. J. Mt. Ecol. 3, 197-201.

Boitani, L., Trapanese, P., Mattei, L., Nonis, D., 1995b. Demography of a wild boar (Sus scrofa, L.) population in Tuscany, Italy. Gibier Faune Sauvag. 12, 109-132.

Bouldoire, J.L., Vassant, J., 1989. Le sanglier. Hatier, Paris.

Bridault, A., 1990. Epipaléolithique et Mésolithique de l'est de la France et du Bassin Parisien: que dit la faune ? Rev. Archéol. Est Cent.-Est 41, 213-222.

Bridault, A., 1993. Les économies de chasse épipaléolithiques et mésolithiques dans le Nord et l'Est de la France. URA 1415 du CNRS “Archéozoologie et Histoire des Sociétés". Université Paris X (308pp.). 
Bridault, A., 1994. Les économies de chasse épipaléolithiques et mésolithiques dans le Nord et l'Est de la France: nouvelles analyses. Anthropozoologica 17, 55-67 (premier semestre 1994)

Bridault, A., 1997. Chasseurs, ressources animales et milieux dans le nord de la France, de la fin du Paléolithique à la fin du Mésolithique: problématique et état de la recherche. In: Fagnart, J.P., Thévenin, A. (Eds.), Le Tardiglaciaire en Europe du nord-ouest. CTHS, Paris, pp. 165-176.

Bridault, A., with collaboration Chiquet, P., 2000. L'exploitation des ressources animales à la Baume d'Ogens (Vaud, Suisse). In: Crotti, P. (Ed.), Méso'97, Actes de la table ronde "Epipaléolithique et Mésolithique", Lausanne, 21-23 novembre 1997, Cahiers d'archéologie romande, $n^{\circ} 81$, pp. 101-108.

Bridault, A., Vigne, J.D., Horard-Herbin, M.P., Pelle, E., Fiquet, P., Mashkour, M., 2000. Wild boar, age at death estimates: the relevance of new modern data for archaeological skeletal material. 1 - presentation of the corpus. Dental and epiphysial fusion ages, Ibex. J. Mt. Ecol. 11-18.

Briedermann, L., 1967. Schwarzild. In: Wagenknecht, E. (Ed.), Die Altersbestimmung des erlegten Wildes. VEB Deutscher Landwirtschartverlag, Berlin, pp. 76-86.

Brochier, J.E., 1999. Couche archéologique, sol archéologique et distributions spatiales: quelques réflexions (géo)archéologiques sur un vieux problème. Geoarqueologia i Quaternari litoral. Memorial M.P. Fumanalpp. 91-95.

Brochier, J.E., 2013. The use and abuse of culling profiles in recent zooarchaeological studies: some methodological comments on "frequency correction" and its consequences. J. Archaeol. Sci. 40, 1416-1420.

Bull, G., Payne, S., 1982. Tooth eruption and epiphysial fusion in pigs and wild boar. In: Wilson, B., Grigson, C., Payne, S. (Eds.), Ageing and Sexing Animal Bones From Archaeological Sites, pp. 55-71.

Carter, R.J., Magnell, O., 2007. Age estimation of wild boar based on molariform mandibular tooth development and its application to seasonality at the Mesolithic site of Ringkloster, Denmark. In: Albarella, U., Dobney, K., Ervynck, A. (Eds.), Pigs and Humans: 10000 years of Interaction. Oxford University Press, pp. 197-217.

Coutard, S., Ducrocq, T., Limondin-Lozouet, N., Bridault, A., Leroyer, C., Allenet, G., Pastre, J.-F. 2010. Contexte géomorphologique, chronostratigraphique et paléoenvironnemental des sites mésolithiques et paléolithiques de Warluis dans la vallée du Thérain (Oise, France). Quaternaire 21, 357-384

Crotti, P., Cupillard, C., 2013. Le Mésolithique du Jura. In: Richard, A., Schifferdecker, F., Mazimann, J.P., Bélet-Gonda, C. (Eds.), Le peuplement de l'Arc Jurassien de la Préhistoire au Moyen Âge, Actes des deuxièmes journées archéologiques frontalières de l'Arc Jurassien, Delle-Boncourt, 16-18 novembre 2007, Annales littéraires de l'Université de Franche-Comté. Presses universitaires de Franche-Comté et Porrentruy, Office de la culture et Société jurassienne d'Emulation, Besançon, pp. 127-142.

Cupillard, C., 1998a. L'abri des Cabônes à Ranchot (Jura). In: Cupillard, C., Richard, A. (Eds.), Les derniers chasseurs-cueilleurs du massif jurassien et de ses marges (13000-5500 avant Jésus-Christ). Centre Jurassien du Patrimoine, Lons-le-Saunier pp. $112-113$.

Cupillard, C., 1998b. L'industrie en matière dure animale. In: Cupillard, C., Richard, A (Eds.), Les derniers chasseurs-cueilleurs du massif jurassien et de ses marges (13000-5500 avant Jésus-Christ). Centre Jurassien du Patrimoine, Lons-le-Saunier, pp. $158-161$.

Cupillard, C., 1998c. Se parer à l'Epipaléolithique et au Mésolithique. In: Cupillard, C., Richard, A. (Eds.), Les derniers chasseurs-cueilleurs du massif jurassien et de ses marges (13000-5500 avant Jésus-Christ). Centre Jurassien du Patrimoine, Lons-leSaunier, pp. 201-204.

Cupillard, C., 2002. Les derniers chasseurs-cueilleurs de l'Est de la France: l'exemple de la Franche-Comté entre 10000 et 6000 BP. In: Bevan, L., Moore, J. (Eds.), Peopling the Mesolithic in a Northern Environment. Archeopress, Oxford, pp. 129-158.

Cupillard, C. (Ed.), 2008. Le Tardiglaciaire et le début de l'Holocène dans le massif du Jura et ses marges. 20000-5000 avant J.-C.: des derniers chasseurs de rennes aux premiers agriculteurs. Projet Collectif de Recherche (PCR) 2005-2008. Rapport 2007. SRA de Franche-Comté et UMR 6249 du CNRS, Laboratoire de Chrono-environnement, Besançon (300 pp.)

Cupillard, C., David, S., 1991. Ranchot, abri des Cabônes. In: Mordant, C., Jeannin, Y., Laurent, H., Piningre, J.-F., Bonvalot, N., Passard, F., Cupillard, C., Guilhot, J.-O. (Eds.), Prospections - Surveys. Gallia Informations, Franche-Comté, pp. 34-37.

Cupillard, C., David, S., 1995. La prédation au Magdalénien final et au Mésolithique, les derniers chasseurs-cueilleurs de l'abri des Cabônes à Ranchot. Eclats d'histoire: 25 000 ans d'héritage, 10 ans d'archéologie en Franche-Comtépp. 104-109.

Cupillard, C., Perrenoud-Cupillard, N., 2003. The Mesolithic of the Swiss and French Jura and its margins: 10150-6000 BP. In: Larsson, L., Kindgren, H., Knutsson, K., Loeffler, D., Åkerlund, A. (Eds.), Mesolithic on the Move. Oxford Books, pp. 82-95.

Cupillard, C., Richard, H., 1999. Epipaléolithique et Mésolithique en zone de moyenne montagne jurassienne: l'exemple de la haute vallée du Doubs (France). In: Thévenin, A., Bintz, P. (Eds.), L'Europe des derniers chasseurs. 5e Colloque international UISPP, 18-23 septembre 1995. CTHS, Paris, pp. 509-519.

Cupillard, C., Magny, M., Bocherens, H., Bridault, A., Bégeot, C., Bichet, V., Bossuet, G., Drucker, D.G., Gauthier, E., Jouannic, G., Millet, L., Richard, H., Rius, D., Ruffaldi, P., Walter-Simonnet, A.-V., 2015. Changes in ecosystems, climate and societies in the Jura Mountains between 40 and $8 \mathrm{ka}$ cal BP. Quat. Int. 1-34 http://dx.doi.org/10. 1016/i.quaint.2014.05.032 (in press, Online, 2014).

D'Errico, F., David, S., 1993. Analyse technologique de l'art mobilier. Le cas de l'abri des Cabônes à Ranchot (Jura). Gall. Préhist. 35 (5), 139-176.

David, S., 1996. La fin du Paléolithique supérieur en Franche-Comté: environnement, cultures, chronologie. Gall. Préhist 38, 111-248.

David, E., 2000. L'industrie en matières dures animales des sites mésolithiques de la Baume d'Ogens et de Birsmatten-Basisgrotte (Suisse), résultats de l'étude technologique et comparaisons. MESO'97, Actes de la Table Ronde "Epipaléolithique et Mésolithique", Lausanne, 21-23 novembre 1997pp. 79-100.
Diong, C.H., 1973. Studies of the Malayan wild pig in Perak and Jahore. Malay. Nat. J. 26, 120-151.

Drucker, D., Bridault, A., Hobson, K.A., Szuma, E., Bocherens, H., 2008. Can carbon-13 in large herbivores reflect the canopy effect in temperate and boreal ecosystems? Evidence from modern and ancient ungulates. Palaeogeogr. Palaeoclimatol. Palaeoecol. 266, 69-82.

Ducrocq, T., Bridault, A., Coutard, S., 2008. Le gisement mésolithique de Warluis (Oise): approche préliminaire. In: Fagnart, J.P., Thévenin, A., Ducrocq, T., Souffi, B., Coudret, P. (Eds.), Le début du Mésolithique en Europe du Nord-Ouest, actes de la table ronde d'Amiens, 9 et 10 octobre 2004. Mémoire de la Société préhistorique française XLV, pp. 85-106.

Ducrocq, T., Bridault, A., Cayol, N., Coutard, S., 2014. Une concentration de vestiges caractéristiques du Beuronien à segments: le gisement de Warluis I (Oise). Rev. Archéol. Picardie 1-2, 1-38.

Etienne, P., 2003. Le sanglier. Delachaux et Niestlé, Neuchâtel.

Frontin, D., 2008 (unpublished). Economie de pêche et diversité piscicole au Mésolithique: le site de l'abri des Cabônes à Ranchot, Mémoire de Master II, Université Paris 1 Panthéon-Sorbonne, Paris, 114 pp.

Genov, P.V., Massei, G., Barbalova, Z., Kostova, V., 1992. Ageing wild boar (Sus scrofa L.) by teeth. In: Spitz, F., Janeau, G., Gonzalez, G., Aulagnier, S. (Eds.), Ongulés/Ungulates. S.F.E.P.M.-I.R.G.M., Paris-Toulouse, pp. 399-402.

Grant, A., 1978. Variation in dental attrition in mammals and its relevance to age estimation. Research Problems in Zooarchaeologypp. 103-105.

Grant, A., 1982. The use of tooth wear as a guide to the age of domestic ungulates. In: Wilson, B., Grigson, C., Payne, S. (Eds.), Ageing and Sexing Animal Bones from Archaeological Sites. BAR British Series, pp. 91-109.

Haber, A., 2007. A statistical method for dealing with isolated teeth: ageing pig teeth from Hagoshrim, Israel. In: Albarella, U., Dobney, K., Ervynck, A. (Eds.), Pigs and Humans: 10000 Years of Interaction. Oxford University Press, pp. 218-227.

Habermehl, K.H., 1975. Die Altersbestimmung bei Haus und Labortieren. Paul Parey Verlag, Berlin \& Hamburg.

Habermehl, K.H., 1985. Altersbestimmung bei Wild- und Pelztieren. Paul Parey Verlag, Berlin.

Hayashi, Y., Nishida, T., Mochizuki, K., Seta, S., 1977. Sex and age estimation of the Japanese wild boar (sus scrofa leucomystax) by the lower teeth. Jpn. J. Vet. Sci. 39, $165-174$.

Higham, C.F.W., 1967. Stock rearing as a cultural factor in Prehistoric Europe. Proc. Prehist. Soc. $33,84-106$

Horard-Herbin, M.P., 1997. Le village celtique des arènes à Levroux, l'élevage et les productions animales dans l'économie de la fin du Second Age du Fer. C.N.R.S./Ministère de la Culture, sous-direction de l'Archéologie/Conseil Général de l'Indre/Conseil Régional du Centre (Archéa.).

Iff, U., 1978. Détermination de l'âge chez le sanglier. Diana 95, 377-381.

Kozlo, P., Nikitenko, M.F., 1967. Methods for ageing wild boar (in Russian). Ecology of Mammals and Birds. Nauka, Moscow, pp. 209-221.

Lauwerier, R.C.G.M., 1983. Pigs, piglets and determining the season of slaughtering. J. Archeol. Sci. 10, 483-488.

Leduc, C., 2005 (unpublished). Le sanglier, une ressource clé dans l'économie des chasseurs de l'abri des Cabônes à Ranchot (Jura) au Mésolithique moyen, Mémoire de DEA, Environnement et Archéologie, Université Paris 1 Panthéon-Sorbonne, Paris, $90 \mathrm{pp}$.

Leduc, C., 2010. Acquisition et exploitation des ressources animales au Maglemosien: essai de reconstitution des chaînes opératoires globales d'exploitation d'après l'analyse des vestiges osseux des sites de Mullerup et Lundby Mose (Sjælland Danemark). Archéologie, Ethnologie, Anthropologie. Université Paris 1 PanthéonSorbonne, Paris, p. 670.

Leduc, C., 2013. Ungulates exploitation for subsistence and raw material, during the Maglemose culture in Denmark: the example of Mullerup site (Sarauw's Island) in Sjælland. Dan. J. Archaeol.

Leduc, C., Bridault, A., Souffi, B., David, E., Drucker, D., 2013. Apports et limites de l'étude des vestiges fauniques à la caractérisation d'un site mésolithique de plein air à Paris: "62 rue Henry-Farman" (15e arrondissement). Bull. Soc. Préhist. Fr. 110, 157-180.

Legge, A.J., 2013. "Practice with science": molar tooth eruption ages in domestic, feral and wild pigs (Sus scrofa). Int. J. Osteoarchaeol. (Online version).

Lemoine, X., Zeder, M.A., Bishop, K.J., Rufolo, S.J., 2014. A new system for computing dentition-based age profiles in Sus scrofa. J. Archaeol. Sci. 47, 179-193.

Magnell, O., 2005. Harvesting wild boar, a study of prey choice by hunters during the Mesolithic in South Scandinavia by analysis of age and sex structures in faunal remains. Archaeofauna 14, 27-41.

Magnell, O., 2006a. Tooth wear in wild boar (Sus scrofa). In: Ruscillo, D. (Ed.), Recent Advances in Ageing and Sexing Animal Bones. Proceedings of the 9th ICAZ Conference, Durham, 2002. Oxbow Books, pp. 189-203.

Magnell, O., 2006b. Tracking Wild Boar and Hunters: Osteology of Wild Boar in Mesolithic South Scandinavia, Lund 2005

Magnell, O., Carter, R., 2007. The chronology of tooth development in wild boar, a guide to age determination of linear enamel hypoplasia in prehistoric and medieval pigs. Vet. Zootech. 40, 43-48.

Marinval-Vigne, M.C., Mordant, D., Auboire, G., Augereau, A., Bailon, S., Dauphin, C., Delibrias, G., Krier, V., Leclerc, A.-S., Leroyer, C., Mordant, C., Rodriguez, P., Vilette, P., Vigne, J.D., 1989. Noyen-sur-Seine, site stratifié en milieu fluviatile: une étude multidisciplinaire intégrée. Bull. Soc. Préhist. Fr. 86, 370-379.

Marquebielle, B., 2014. Le travail des matières osseuses au Mésolithique. Caractérisation technique et économique à partir de séries du Sud et de l'Est de la France. Université de Toulouse II - Jean Jaurès, Toulouse (Thèse de doctorat, 508 pp.).

Matschke, G.H., 1967. Ageing European wild hogs by dentition. J. Wildl. Manag. 31, 109-113. 
Mauget, R., 1981. Behavioural and Reproductive strategies in wild forms of Sus scrofa (European wild boar and feral pigs). In: Sybesma, W. (Ed.), The Welfare of Pigs. Current Topics in Veterinary Medicine and Animal Science Martinus Nijhoff, Brussels, pp. 3-13.

Mauget, R., 1984. Rythme d'activité et budget-temps chez le sanglier européen (Sus scrofa L.). Symposium international sur le sanglier. I.N.R.A., Toulouse, pp. 79-92 (avril 1984).

Mauget, R., Campan, R., Spitz, F., Dardaillon, M., Janeau, G., Pépin, D., 1984. Synthèse des connaissances actuelles sur la biologie du sanglier, perspectives de recherche. Symposium international sur le sanglier. I.N.R.A., Toulouse, pp. 15-50 (avril 1984).

Mayer, J.J., Brisbin Lehr, I.J., 1988. Sex identification of Sus scrofa based on canine morphology. J. Mammal. 69, 408-412.

McCance, R.A., Ford, E.H.R., Brown, W.A.B., 1961. Severe undernutrition in growing and adult animals, 7. Development of the skull, jaws and teeth in pigs. Br. J. Nutr. 15, 213-224.

Munson, P.J., Garniewicz, R.C., 2003. Age-mediated survivorship of ungulate mandibles and teeth in canid-ravaged faunal assemblages. J. Archaeol. Sci. 30, 405-416.

Pépin, D., 1991. Alimentation, croissance et reproduction chez la laie: études en conditions naturelles et en captivité. Inra Prod. Anim. 4, 183-189.

Pignat, G., Winiger, A., 1998. Les occupations mésolithiques de l'abri du Mollendruz. Abri Freymond, commune de Mont-La-Ville (VD Suisse), Cahiers d'Archéologie Romande Lausanne.

Poplin, F., 1976a. A propos du nombre de restes et du nombre d'individus dans les échantillons d'ossements. Cah. Cent. Rech. Préhist. 5, 61-74.

Poplin, F., 1976b. Remarques théoriques et pratiques sur les unités utilisées dans les études d'ostéologie quantitative, particulièrement en archéologie préhistorique, actes du IXe congrès. Union Internationale des Sciences Préhistoriques et Protohistoriques, Thèmes spécialisés, Parc Valrose de l'Université de Nice, 13-18 septembre 1976pp. 125-141.

Rolett, B.V., Chiu, M.Y., 1994. Age estimation of Prehistoric pigs (Sus scrofa) by molar eruption and attrition. J. Archaeol. Sci. 21, 377-386.

Roué, S., 2000. Les armatures mésolithiques de l'abri des Cabônes à Ranchot (Jura). In: Richard, A., Cupillard, C., Richard, H., Thévenin, A. (Eds.), Les derniers chasseurscueilleurs d'Europe occidentale (13000-5500 av. J.-C.). Actes du Colloque international de Besançon (Doubs, France), 23-25 Octobre 1998. Presses Universitaires Franc-Comtoises, Collection Annales Littéraires, Besançon, pp. 133-141.

Rowley-Conwy, P., 1993. Season and reason, the case for a regional interpretation of Mesolithic settlements patterns. In: Peterkin, G.L., Bricker, H., Mellars, P. (Eds.), Hunting and Animal Exploitation in the Later Palaeolithic and Mesolithic of Eurasia, $\mathrm{N}^{\circ} 4$, Chap. 13, Archaeological Papers of the American Anthropological Association, pp. 179-188.

Santos, P., Fernández-Llario, P., Fonseca, C., Monzón, A., Bento, P., Soares, A.M.V.M., Mateos-Quesada, P., Petrucci-Fonseca, F., 2006. Habitat and reproductive phenology of wild boar (Sus scrofa) in the western Iberian Peninsula. Eur. J. Wildl. Res. 52, 207-212.

Schmid, E., 1963. Die Tiercknochen. In: Bandi, H.-G. (Ed.), Birsmatten-Basisgrotte: eine mittelsteinzeitliche Fundstelle im unteren Birstal, Stämpli, Bern, pp. 72-83.

Schmid, E., 1972. Atlas of animal bones for Prehistorians, Archaeologists, Quaternary Geologists/Knochenatlas für Prähistoriker, Archäologen und Quärtargeologen. Elsevier Publishing Company, Amsterdam/London/New York.

Séara, F., Roncin, O., 2010. Dammartin-Marpain (Jura), Prairie du Milieu. Nouvelles données sur le peuplement mésolithique, néolithique, protohistorique et antique de la basse vallée de l'Ognon. Rapport final d'opération, Inrap Grand Est sud, Dijon.

Séara, F., Roncin, O., 2013. Fonds de vallée et fréquentation mésolithique: l'exemple de Dammartin-Marpain dans le Jura. In: Valentin, B., Souffi, B., Ducroca, T., Fagnart, J.-P. Séara, F., Verjux, C. (Eds.), Palethnographie du Mésolithique: recherches sur les habitats de plein air entre Loire et Neckar/Mesolithic Palethnography: Researchs on open-air campsites from the river Loire to the Neckar, Actes de la table ronde internationale de Paris, 26 et 27 Novembre 2010. Société préhistorique française, Paris, pp. 93-115.

Séara, F., Rotillon, S., Cupillard, C., Séara, F., Rotillon, S., Cupillard, C., 2002. Campements mésolithiques en Bresse jurassienne: Choisey, Ruffey-sur-Seille (Jura). Documents d'Archéologie Française, Edition de la Maison des Sciences de l'Hommep. 338.

Séara, F., Bridault, A., Ducrocq, T., Souffi, B., 2010. Chasser au Mésolithique, l'apport des sites de vallées du quart nord-est de la France, Archéopages. Dossier “Chasses”, La Documentation Française, Parispp. 26-35.

Silver, A., 1969. The ageing of domestic animals. In: Brothwell, R., Higgs, E.S. (Eds.), Science in Archaeology, 1st Edition, 1963 ed. Thames and Hudson, London, pp. 283-302.

Valentin, F., 1998. Les restes humains de l'abri des Cabônes à Ranchot. In: Cupillard, C., Richard, A. (Eds.), Les derniers chasseurs-cueilleurs du massif jurassien et de ses marges (13000-5500 avant Jésus-Christ). Centre Jurassien du Patrimoine, Lons-leSaunier, pp. 185-186.

Varin, E., 1977. Sangliers, l'âge d'après les dents. Rev. Natl. Chass. 55-60.

Varin, E., 1980. Chevreuil, cerf, sanglier, 2e éd (revue et augmentée). Les éditions de l'Orée, Bordeaux.

Vassant, J., Brandt, S., Nivois, E., Baubet, E., 2010. Le fonctionnement des compagnies de sangliers. Faune sauvage.

Wright, E., Viner-Daniels, S., Parker Pearson, M., Albarella, U., 2014. Age and season of pig slaughter at Late Neolithic Durrington Walls (Wiltshire, UK) as detected through a new system for recording tooth wear. J. Archaeol. Sci. 52, 497-514. 